\title{
Deskripsi Sejarah Konflik Horizontal Orang Yahudi dan Samaria
}

\author{
An Historical Analysis of Horizontal Conflict \\ between Jews and Samaritan
}

\author{
Yonatan Alex Arifianto \\ STT Sangkakala, Salatiga \\ arifianto.alex@gmail.com
}

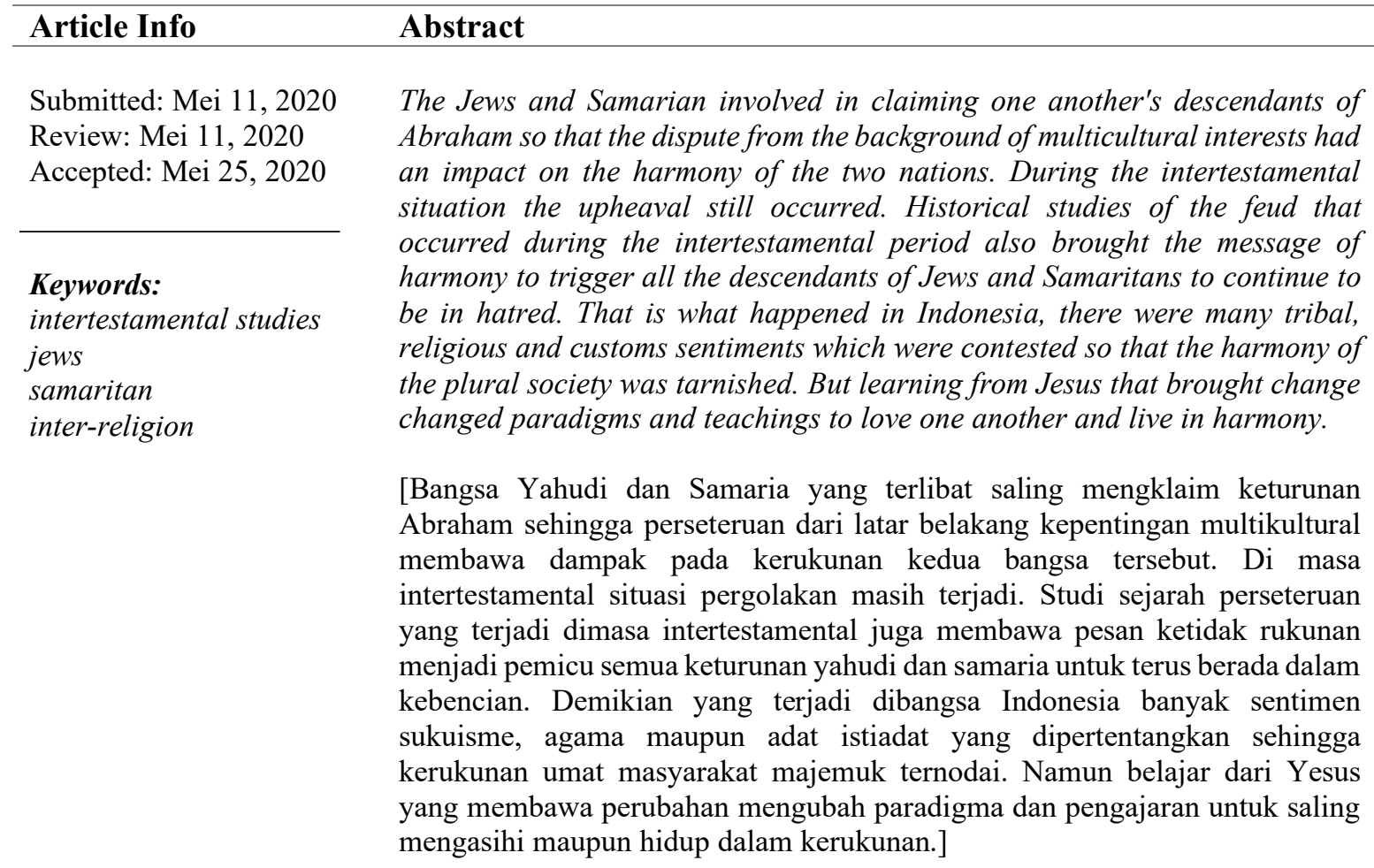




\section{PENDAHULUAN}

$\mathrm{D}$ alam perjalanan ke Galilea, Yesus berhenti di sumur Yakub di wilayah Orang Samaria (Yohanes 4:4). Di dekat sumur itu Yesus berjumpa dengan seorang perempuan Samaria dan berbincang dengannya. Injil Yohanes mencatat pokok percakapan keduanya adalah air kehidupan dan penyembahan. Penyataan Yesus yang sangat terkenal bahwa penyembahan bukan dilakukan baik di Gunung Gerizim maupun di Gunung Moria. Di masing-masing puncak gunung itu terdapat bangunan rumah ibadah Yahudi dan Samaria. Yohanes mencatat dua perkataan Yesus yang penting. Pertama, "Percayalah kepada-Ku, hai perempuan, saatnya akan tiba, bahwa kamu akan menyembah Bapa bukan di gunung ini dan bukan juga di Yerusalem (Yohanes 4:21); Kedua, Tetapi saatnya akan datang dan sudah tiba sekarang, bahwa penyembah-penyembah benar akan menyembah Bapa dalam roh dan kebenaran; sebab Bapa menghendaki penyembah-penyembah demikian. (Yohanes 4:23). Akan tetapi yang membuat percakapan keduanya menarik adalah bingkai yang disematkan Yohanes di dalam injil-Nya bahwa secara faktual historis, percakapan Yesus dan perempuan Samaria itu seharusnya tidak terjadi. Di dalam Yohanes 4:9 secara tegas dikatakan bahwa "Orang Yahudi tidak bergaul dengan orang Samaria." Yesus pasti sadar akan situasi tersebut karena Yesus adalah seorang Rabi Yahudi. Tetapi secara sadar dan sengaja, Yesus terlihat mengesampingkan perseteruan historis yang terbentang ratusan tahun antara orang-orang Yahudi di Yerusalem dan orang Samaria di Utara.

Di bagian Injil lain-nya, sekali lagi Yesus juga terlihat sengaja memasukan orang Samaria sebagai kriteria 'baik hati' dalam sebuah perumpamaan tentang orang yang dirampok di sebuah jalan menurun ke arah Yerikho. Seorang imam yang turun melalui jalan itu hanya melewati dari seberang jalan. Demikian juga saat seorang Lewi datang ke tempat itu, juga melewatinya dari seberang jalan. Respon berbeda datang dari seorang Samaria yang langsung memberi pertolongan karena digerakkan oleh belas kasihan pada korban yang tergeletak tidak berdaya. Bukan hanya merawat dan membalut luka, korban diangkut dan dititipkan disebuah penginapan dengan menanggung biayanya (Lukas 10:31-34). Yesus tidak kebetulan memilih orang Samaria, sebagai pribadi yang peduli pada sesama di dalam cerita itu, tetapi faktualnya dibenci dan dimusuhi oleh orang Yahudi. Jika ditarik mundur kebelakang, gambaran perumpamaan Yesus bertujuan memberikan pengertian dan membangun kesadaran di kalangan orang-orang Yahudi bahwa kepedulian terhadap sesama, sama pentingnya dengan praktik agama. Jawaban atas pertanyaan seorang ahli Taurat mengenai siapakah yang disebut sesama manusia itu, ditutup dengan tegas oleh pernyataan Yesus di akhir cerita. Siapakah di antara ketiga orang ini, menurut pendapatmu, adalah sesama manusia dari orang yang jatuh ke tangan penyamun itu?" Ahli Taurat itu serta-merta menjawab "Orang yang telah menunjukkan belas kasihan kepadanya." Kata Yesus kepadanya: "Pergilah, dan perbuatlah demikian!" (Lukas 10:36-37).

Kisah pertikaian dan narasi kebencian juga muncul pada saat Yesus bersama Yakobus dan Yohanes melintasi kota Samaria. Penduduk kota itu serempak menolak rombongan itu. Lukas mencatat respon rasial dari kedua murid Yesus itu. "Tuhan, apakah Engkau mau, supaya kami menyuruh api turun dari langit untuk membinasakan mereka?" (Lukas 9:54). Pernyataan yang dilontarkan kedua murid Yesus tersebut menggambarkan sebuah sentimen kebencian yang mendalam terhadap orang Samaria, hingga berani memprovokasi Yesus untuk menghancurkan desa tersebut. Terlebih dalam anggapan orang Yahudi, orang-orang Samaria itu tidak lagi dianggap sebagai ras murni keturunan Abraham karena telah bercampur dengan orang asing. ${ }^{1}$

Melalui penelitian ini, penulis akan meneliti akar permusuhan tersebut dengan melihat beberapa pandangan di dalam Perjanjian Lama (PL), di dalam Perjanjian Baru (PB) dan secara khusus di dalam masa intertestamental (MI). Penulis berharap dengan melakukan penggalian sejarah maka akan terungkap apa yang menjadi akar konflik berkepanjangan antara Yahudi dan Samaria. Penjelasannya diharapkan dapat menjadi model untuk membedah masalah yang sama, konflik horizontal antar umat beragama dimanapun terjadi.

${ }^{1}$ LAI, Alkitab Penuntun Hidup Berkelimpahan (Malang: Gandum Mas, 2012),2090. 


\section{METODE}

Jenis penelitian dalam paper ini adalah penelitian pustaka dengan pendekatan kualitatif deskriptif. ${ }^{2}$ Penekanannya adalah pada kajian sejarah terhadap sumber-sumber pustaka dan menguraikannya dalam sebuah kerangka uraian sebagai berikut. Analisis dimulai dari pecahnya monarkhi Israel pasca kekuasaan Salomo, kemudian deskripsi kehancurnya di tangan Asyur dan tinjauan di dalam masa intertestamental. Kajian secara khusus diarahkan untuk meneliti akar permasalahan dan dinamika konflik yang berlangsung antara Yahudi dan Samaria. Sumber utama adalah narasi di dalam Alkitab sebagai referensi sejarah, yang dilengkapi oleh berbagai buku dan sumber akademik lainnya yang relevan dengan topik. Sumber-sumber literatur tersebut dioleh menjadi rangkaian analisis mengikuti prinsip literatur review yang dimaksud oleh Denney. ${ }^{3}$ Sebagai sebuah penelitian sejarah maka penyajiannya dilakukan secara deskriptif.

\section{PEMBAHASAN}

\section{Bermula dari Pecahnya Monarkhi}

Menurut 1 Raja-raja 16: 24 kota Samaria, sebagai ibu kota baru, dibangun oleh Raja Omri enam tahun sesudah memerintah di utara. Secara geografis berada di atas bukit pegunungan Palestina sebelas kilo meter di Barat Laut Sikhem. Kota ini tepat berada di jalur perdagangan utama yang melalui dataran Esdraelon. Pada Tahun 870 sebelum Masehi (1 Raja-raja 16 : 24) Raja Omri membeli daerah gunung Samaria seharga dua talenta perak, dan memberikan nama menurut pemilik tanah yang bernama Semer. ${ }^{4}$ Omri juga mengizinkan orang Aram dari Damsyik mendirikan beberapa pasar di kota Samaria seperti yang diungkapakan dalam kitab Raja-raja (1Raja-Raja 20:34). Samaria adalah sebuah istilah geografis yang digunakan untuk wilayah pegunungan antara Galilea di Utara dan Yudea di Selatan. Nama ini digunakan untuk wilayah alam, historis, dan politik. Daerah ini terletak di tengah Tanah Israel di dalam Alkitab.

Alkitab mencatat banyak kisah mengenai Samaria. Yesaya mencatatnya sebagai ibu kota suku Efraim (Yesaya 7 : 9). Samaria menjadi tempat yang khusus bagi raja-raja Israel dikuburkan. Omri dan Yoas dikuburkan di pegunungan itu (1 Raja-Raja 16:28; 2 Raja-Raja 13:13). Samaria juga pernah menjadi tempat tinggal nabi Elisa ketika terjadi pengepungan Aram terhadap kota itu sehingga penduduknya menderita kelaparan (1 Raja-Raja 6:25-29). Akan tetapi, penduduk kota itu digambarkan oleh Yesaya memiliki sifat congkak dan tinggi hati, karakter yang sangat tidak berkenan kepada Tuhan. Demikian juga menurut Yehezkiel mengungkapkan sifat jahat penduduknya melalui berbagai perbuatan keji (Yehezkiel $16: 46-47)$. Nabi Amos ikut mencatat bahwa orang-orang ini hidup di dalam penyembahan berhala yang kuat (Amos $8: 14$ ).

Orang Samaria mengklaim bahwa mereka sejatinya adalah keturunan dari Israel dari sukusuku Israel Utara, yakni dari Efraim dan Manasye dari keturunan Yusuf, yang selamat dari kehancuran Kerajaan Israel (Samaria) akibat serbuan Asyur pada 722 SM. Sebelum peristiwa Omri mendirikan Kota Samaria, terjadi perpecahan di kerajaan Israel setelah Salomo meninggal. Rehabeam menggantikan Salomo namun sepuluh suku di Utara di bawah pimpinan Yerobeam memutuskan mendirikan pemerintahan sendiri terpisah dari Yehuda dan membangun tempat (kota) bagi pemerintahannya. ${ }^{5}$ Pemisahan diri itu juga disertai dengan keputusan mendirikan tempat ibadah bagi sepuluh suku. Selain memutuskan Sikhem sebagai ibu kota pertama Israel dan diklaim sebagai pilihan Allah untuk tempat kediamanNya, berbanding terbalik dengan pengakuan orang Yahudi

2 Sonny Eli Zaluchu, "Strategi Penelitian Kualitatif Dan Kuantitatif Di Dalam Penelitian Agama," Evangelikal 4, no. 1 (2020): 28-38.

3 Andrew S. Denney and Richard Tewksbury, "How to Write a Literature Review," Journal of Criminal Justice Education 24, no. 2 (2013): 218-234.

${ }^{4}$ J.D. Douglas, ed., Ensiklopedi Alkitab Masa Kini Jilid 2 M-Z, 5th ed. (Jakarta: Yayasan Komunikasi Bina Kasih/OMF, 2005)..

${ }^{5}$ Stephen M. Miller, Panduan Lengkap Alkitab, ed. Windiasih Sairoen, Ellia Erliani, and Rika Uli Napituulu-Simarangkir, 1st ed. (Jakarta: BPK Gunung Mulia, 2020), 117. 
yang tetap percaya bahwa kota Yerusalemlah sebagai kediaman-Nya yang sejati. ${ }^{6}$ Pertengkaran utama kedua "suku bangsa" ini bermula dari persaingan religi dan klaim meng-klaim bahwa Allah yang hidup tinggal di Sikhem, bukan di Yerusalem. Demikian sebaliknya menurut pandangan suku Yehuda. Klaim Samaria diperkuat dengan tulisan Musa dimana Allah menjanjikan suatu negeri kepada Abraham (Kejadian $12: 6-7$ ) dan sebagai tempat dimana Yosua memperbaharui perjanjian antara Allah dengan umat-Nya (Yosua $24: 1-27$ ). ${ }^{7}$

\section{Kerajaan Utara Hancur}

Latar belakang terbentuknya kota samaria dan segala karakter penduduk yang diungkapkan oleh nabi-nabi mengerucut terhadap apa yang ditulis oleh Kitab 2 Raja-Raja $17: 24$, yaitu kekalahan Israel terhadap Asyur. Setelah Isarel jatuh ke tangan bangsa Asyur, Raja Asyur membawa masuk orang-orang dari Babel, dari Kuta, dari Awa dari Hemat dan Sefarwaim lalu menduduki dan menetap di kota-kota Samaria menggantikan orang Israel yang diangkut keluar menuju Asyur sebagai tawanan. Tindakan tersebut ditempuh untuk mencegah terjadinya pemberontakan. ${ }^{8}$ Orang-orang asing tersebut diharapkan menjadi penyeimbang dan membantu menjaga perdamaian bagi kerajaan Asyur di wilayah Utara. Akibatnya perkawinan campuran antara orang-orang asing tersebut dengan orang-orang Yahudi yang tersisa tidak dapat dihindari. Lahirlah satu generasi ras campuran, yang tidak murni menurut pandangan orang Yahudi yang tinggal di Selatan. Akar kebenciannya bermula dari perkara ini. ${ }^{9}$ Ingrid Hjelm mengungkapkan dalam bukunya The Samaritans and Early Judaism A Literary Analysis bahwa asal mula orang Samaria telah dihasilkan dari masuknya koloni kafir di kerajaan Utara setelah jatuhnya Samaria. ${ }^{10}$ Koloni ini ikut membawa budaya dan sistem agama di seluruh wilayah Utara. Beamount mengatakan bahwa orang Asyur menganut sisten religi politeisme, yang percaya pada dewa-dewa Mesopotamia kuno dan dewa-dewa baru. Bangsa inilah yang pertama kali memperkenalkan surat doa untuk ditujukan kepada dewa. ${ }^{11}$ Belakangan, kebiasaan itu dipergunakan juga oleh Hizkia, Raja Yehuda, ketika sedang sakit parah dan berkomunikasi kepada Tuhan melalui surat.

Menurut McElrath dan Billy, Samaria tetap merupakan sebuah bangsa yang berkaitan erat dalam hubungan keluarga dan agama dengan bangsa Yahudi. ${ }^{12}$ Setelah dikuasai Asyur wilayah tersebut dikendalikan oleh Kekaisaran Persia. Samaria menjadi ibu kota propinsi sampai saat Nehemia memperoleh kekuasaan untuk Yehuda dan menolak orang Samaria (Ezra $4: 2-3$ ). ${ }^{13}$ Selain terkontaminasi dalam hal ras, penolakan terhadap Samaria bertitik tolak dari perubahan sistem religi yang dialami bangsa itu. Elohim bukan lagi menjadi pusat penyembahan karena digantikan oleh berbagai baal dan berhala yang ditempatkan Asyur sewaktu masih menguasai kawasan tersebut. Seperti yang diungkapkan Gene Getz, orang Samaria terus menerus menyertakan segi-segi agama kafir di dalam setiap ibadah yang dilakukan. ${ }^{14}$ Dimana-mana berdiri kuil sebagai tempat penyembahan bagi dewa-dewa Ayur yang terkenal seperti penyembahan bagi Baal yang disponsori oleh Izebel atas nama Raja Ahab (1Raja-Raja 18:22) dan hadirnya pilar untuk asyera di dekat mezbah yang semula bagi Elohim. ${ }^{15}$ Sehingga dalam kurun waktu yang sangat lama, Samaria

${ }^{6}$ Packer J.I, Meryl C. Tenney, and William White, Ensiklopedi Fakta Alkitab (Malang: Gandum Mas, 2009), 830.

${ }^{7}$ Mike Beaumont, Ensiklopedi Alkitab, Alkitab (Tematik, Jakarta: Yayasan Bina Kasih, 2019).

${ }^{8}$ LAI, Alkitab Penuntun Hidup Berkelimpahan.

${ }^{9}$ LAI, Alkitab Penuntun Hidup Berkelimpahan, 786.

${ }^{10}$ Nicolae Roddy and Ingrid Hjelm, "The Samaritans and Early Judaism: A Literary Analysis," Journal of Biblical Literature 120, no. 3 (2001): 557.

${ }^{11}$ Beaumont, Ensiklopedi Alkitab, 72-73. Baptis, 2003).

12 Billy Mathias and Mcelrath W N, Ensiklopedia Alkitab Praktis (Bandung: Lembaga Literatur

${ }^{13}$ Herbert Haag, Kamus Alkitab (Flores: Penerbit Nusa Indah, 2002).

${ }^{14}$ Gene Getz, Pedoman Lengkap Pendalama Alkitab Tentang Uang Dan Harta (Bandung: Kalam Hidup, 2008), 125.

${ }^{15}$ Douglas, Ensiklopedi Alkitab Masa Kini Jilid 2 M-Z, 350. 
dianggap oleh para nabi sebagai pusat penyembahan berhala (Yesaya 8:4; 9:9 ; Yeremia 23:13; Yehezkiel 23:4; Hosea 7:1 dan Mikha 1:6 ). ${ }^{16}$

Herbert Haag bahkan melihat dualisme di dalam sistem religi dan praktik keagamaan. Bangsa campuran ini ternyata masih menyembah Yahweh sebagai Allah Negara (1Raja-Raja 17:2528) tetapi juga menghormati para dewa Asyur (1Raja-Raja 17:2 -34). ${ }^{17}$ Semua kejadian tersebut terpampang di depan mata saudara sesuku yang tinggal Yerusalem sepanjang waktu. Terlebih dalam rencana pembangunan kembali tembok Yerusalem di masa angkatan yang kembali dari pembuangan. Kelompok ini dipimpin oleh Ezra dan menerima keinginan orang Samaria untuk bergabung di dalam pembangunan tersebut. Kenyataannya, keinginan tersebut hanya merupakan kepura-puraan (Ezra 4:2). Semua ini akhirnya menjadi indikator sejarah bagi keturunan Israel asli untuk berseberangan dengan keturunan orang-orang Samaria. ${ }^{18}$

\section{Masa Intertertestamental}

Masa Intertestamental adalah periode sejarah yang terbentuk antara Perjanjian Lama (PL) dengan Perjanjian Baru (PB). Secara tradisional, periode ini dianggap mencakup kira-kira empat ratus tahun, dimana masa setelah Ezra dan Nehemia pulang ke tanah mereka kembali dan membangun kembali negeri dan kelanjutan dari zaman ini merupakan zaman yang dikenal dengan nama periode Intertestamental (masa antar perjanjian). ${ }^{19}$

Masa ini juga dikenal dengan sunyi. Disebut demikian karena sejak nubuatan nabi Maleakhi, tidak ada lagi pernyataan dari Elohim kepada Israel hingga masa dimana Kristus lahir ke dunia. Sikap diam Elohim kepada umatNya itu digambarkan sebagai sebuah kesunyian (silent ages) kendatipun sejarah dan aktifitas umat Tuhan tetap berjalan. Istilah lain yang sering dipergunakan adalah Intertestamental Period (Masa antar Perjanjian). Tidak ada nabi yang dibangkitkan atau raja yang diurapi untuk memimpin umat-Nya. Terlebih pada masa itu, tidak muncul surat-surat nabi atau pewahyuan Elohim karena PL sudah dianggap tuntas atau sudah selesai.

Pembagian masa intertestamental dapat dibagi kedalam empat bagian yaitu, masa Periode Persia ( 450 -333 SM ), masa periode Yunani, masa periode Yahudi (Makabe/Hasmoni) dan masa periode Romawi. Dimasa Periode Romawi berlangsung konflik bersenjata orang-orang Yahudi yang ingin merdeka dari penjajahan Romawi. Orang-orang Yahudi tidak bisa menerima peraturan dan segala hukum yang berkaitan langsung dengan kehidupan bermasyarakat maupun segala bentuk intervensi dari pemerintah Romawi terhadap kehidupan keagamaan yang telah dijalankan selama ini. Hal ini memicu pemberontakan yang hampir tidak pernah padam dan terus berkelanjutan di kawasan tersebut.

Ketika kerajaan Persia runtuh pada tahun 333 SM, dan orang Makedonia di bawah pimpinan Alexander Agung maju melalui daerah pesisir Siria menuju Mesir, Yerusalem menjadi kota yang menyerah kepada orang Makedonia. Tidak lama berselang, pada tahun 332 SM Samaria memberontak. Alexander Agung mengirim penduduk baru dari Yunani untuk tinggal disana. Dengan demikian, kembali terjadi percampuran antara "penduduk asli" dengan keturunan Yunani (Makedonia). Peristiwa akulturasi dalam ras, sosial dan agama, kembali terulang di kawasan tersebut. Kebudayaan Yunani memberi dampak signifikan di Utara.

Catatan papirus-papirus yang baru ditemukan di gua Wadi ed-Daliyeh, $14 \mathrm{~km}$ di utara Yerikho, nampaknya menguatkan kesaksian ahli sejarah kuno bahwa mula-mula Samaria meminta pada Alexander untuk merebut kota itu dari Persia pada tahun 331 SM. Tetapi pada saat tiba Alexander di Mesir, orang Samaria membunuh gubernur Siria yang dilantik oleh Alexander.

\footnotetext{
${ }^{16}$ Gary N. Knoppers, Jews and Samaritans: The Origins and History of Their Early Relations, Jews and Samaritans: The Origins and History of Their Early Relations, 2013.

${ }^{17}$ Haag, Kamus Alkitab, 394.

${ }^{18}$ Roddy and Hjelm, "The Samaritans and Early Judaism: A Literary Analysis,” 240-241.

19 Wen Willyam, Logos, Memra, Dan Yesus:: Sebuah Studi Tentang Pengaruh Konsep Logos Yudaisme Helenisme, Memra Yudaisme Palestina Terhadap Konsep Logos Perjanjian Baru (galilee Press, 2018), 32.
} 
Kemarahan Alexander terhadap kejadian tersebut berujung pada pembinasaan Samaria, pembunuhan pemimpin-pemimpin kota di dalam gua tempat pelarian mereka, dan penempatan orang-orang Makedonia untuk mendiami kawasan tersebut. ${ }^{20}$

Pada zaman Helenis (325-363 SM) Samaria membuat manuver yang membangkitkan kebencian orang-orang Yahudi di Yerusalem. Sebab selama Salomo membangun Bait Suci, seluruh kegiatan dan pusat penyembahan terpusat di Yerusalem. ${ }^{21}$ Penolakan terhadap orang Samaria untuk ikut berdoa di Bait Allah Yerusalem menjadi salah satu penyebabnya. Orang Samaria mengalah, menarik diri lalu mendirikan tempat ibadah di Sikhar. Di titik itu satu kepercayaan yang berbeda telah terbentuk. Mereka menantikan Musa sebagai Taheb (pemulih, Mesias) dan menganggap Gunung Gerizim sebagai tempat yang ditetapkan Allah untuk mempersembahkan korban (Yoh. 4:19-20). Tidak peduli terhadap ritual di Yerusalem, orang-orang Samaria menciptakan sistem penyembahan sendiri, baik pada hari paskah, purim dan Hanukkah dan sejumlah perayaan lainnya. Kitab suci yang dipegang hanya lima kitab Musa saja dan menolak semua tulisan kitab-kitab kanonik lainnya. Perbedaan-perbedaan ini menambah daftar panjang kebencian historis antara YahudiSamaria.

Hirkanus pada kurun waktu 111-107 SM pernah melakukan pengepungan terhadap Samaria. Kejadian pengepungan itu membuat desa-desa diratakan dengan tanah dan dihancurkan. Akan tetapi, Pompeius dan Gabinus kembali membangun kota tersebut dari reruntuhan dan diperindah oleh Raja Herodes dan selanjutnya mengubah nama kota itu menjadi Sebastia (Agusta) dalam usahanya merebut hati Kaisar Romawi masa itu. Di dalam kota itu ditempatkan enam ribu orang veteran, termasuk orang-orang Yunani. Sesudah Herodes meninggal, maka kota itu menjadi bagian Wilayah Arkhelaus.

Dengan demikian dapat dilihat bahwa masa intertestamental ikut menjadi masa penajaman konflik dan naik turunnya hubungan domestik antara Samaria di Utara dan Yahudi di Selatan. Di dalam masa ini isu pokok yang terlihat adalah perbedaan di dalam kehidupan beragama dan ritual, yang berujung pada persaingan ibadah dan klaim atas kebenaran. Yahudi di Yerusalem merasa sebagai pihak yang paling murni dan mewarisi status umat pilihan. Sebaliknya, Samaria membangun kepercayaan yang dianggap sebagai pengejawantahan kebenaran sejati melalui peribadatan di Gunung Gerizim. Konflik ini tidak pernah selesai dan turun secara generasional, sehingga membawa narasi kebencian diantara kedua komunitas itu berasal dari sejarah yang panjang. ${ }^{22}$

\section{KESIMPULAN}

Sejarah yang tidak terselesaikan dalam hubungan Yahudi-Samaria tampil di dalam sebuah konsep penyelesaian melalui pelayanan, pengajaran dan perumpamaan Yesus. Kasih Yesus pada semua orang sama. Baik pada orang Yahudi, orang Samaria dan non Yahudi. Detail yang paling terlihat adalah keberanian Yesus mendobrak kebekuan dengan membuka komunikasi dan meruntuhkan tembok penghalang, yang telah berlangsung ratusan tahun. Hanya dengan edukasi dan contoh konkrit, sikap rasis Yahudi dan kecenderungan menganggap rendah orang Samaria, dapat ditekan dan dihilangkan. Pernyataan Yesus dalam Lukas 10:29-37 memperlihatkan hal tersebut terang benderang, bahwa yang disebut sesama manusia bukanlah sesama umat beragama, atau sesama ras. Melainkan, orang-orang yang menjadi objek belas kasihan. Yesus menegaskan bahwa kasih yang sejati bukanlah pengetahuan agama tentang kasih itu tetapi praktik dan perilaku kasih yang terlihat pada siapapun, terlebih pada "mereka" yang membutuhkan.

Sama halnya dengan pola konfik yang terjadi antara Yahudi dan Samaria, demikian juga terlihat pola dan framing yang sama di dalam berbagai peristiwa konflik horizontal antar-umat beragama di Indonesia. Hegemoni satu agama di atas agama lainnya memperlihatkan adanya kecenderungan konflik yang terus berulang di sepanjang sejarah dengan pemicu yang berbeda-beda.

${ }^{20}$ Douglas, Ensiklopedi Alkitab Masa Kini Jilid 2 M-Z, 352.

${ }^{21}$ Jan Christian Gertz et al., Purwa Pustaka - Eksplorasi Ke Dalam Kitab-Kitab Perjanjian Lama Dan Deuterokanonika (Jakarta: BPK Gunung Mulia, 2012), 82.

22 Onesimus, Daryatno Suprianto Dani, Merentang Sejarah, Memaknai Kemandirian: Menjadi Gereja Bagi Sesama (Jakarta: BPK Gunung Mulia, 2009), 5. 
Di dalam hal ini, selama tidak ada komunikasi yang baik antara pemeluk agama dan sikap saling menghargai keyakinan masing-masing, maka potensi konflik dapat terus berlangsung, menunggu momentum untuk muncul ke permukaan. Membuka dialog dan mengembangkan rasa hormat antar pemeluk agama yang berbeda adalah solusi yang terbukti mengalahkan ego sektarian dan identitas kelompok.

\section{REFERENSI}

Beaumont, Mike. Ensiklopedi Alkitab. Alkitab. Tematik, Jakarta: Yayasan Bina Kasih, 2019.

Dani, Suprianto, and Onesimus Daryatno. Merentang Sejarah, Memaknai Kemandirian: Menjadi Gereja Bagi Sesama. Jakarta: BPK Gunung Mulia, 2009.

Denney, Andrew S., and Richard Tewksbury. "How to Write a Literature Review." Journal of Criminal Justice Education 24, no. 2 (2013): 218-234.

Douglas, J.D., ed. Ensiklopedi Alkitab Masa Kini Jilid 2 M-Z. 5th ed. Jakarta: Yayasan Komunikasi Bina Kasih/OMF, 2005.

Gertz, Jan Christian, Angelica Berlejung, Konrad Schmid, and Markus Witte. Purwa Pustaka Eksplorasi Ke Dalam Kitab-Kitab Perjanjian Lama Dan Deuterokanonika. Jakarta: BPK Gunung Mulia, 2012.

Getz, Gene. Pedoman Lengkap Pendalama Alkitab Tentang Uang Dan Harta. Bandung: Kalam Hidup, 2008.

Haag, Herbert. Kamus Alkitab. Flores: Penerbit Nusa Indah, 2002.

J.I, Packer, Meryl C. Tenney, and William White. Ensiklopedi Fakta Alkitab. Malang: Gandum Mas, 2009.

Knoppers, Gary N. Jews and Samaritans: The Origins and History of Their Early Relations. Jews and Samaritans: The Origins and History of Their Early Relations, 2013.

LAI. Alkitab Penuntun Hidup Berkelimpahan. Malang: Gandum Mas, 2012.

Mathias, Billy, and Mcelrath W N. Ensiklopedia Alkitab Praktis. Bandung: Lembaga Literatur Baptis, 2003.

Miller, Stephen M. Panduan Lengkap Alkitab. Edited by Windiasih Sairoen, Ellia Erliani, and Rika Uli Napituulu-Simarangkir. 1st ed. Jakarta: BPK Gunung Mulia, 2020.

Roddy, Nicolae, and Ingrid Hjelm. "The Samaritans and Early Judaism: A Literary Analysis." Journal of Biblical Literature 120, no. 3 (2001): 557.

Wen Willyam. Logos, Memra, Dan Yesus:: Sebuah Studi Tentang Pengaruh Konsep Logos Yudaisme Helenisme, Memra Yudaisme Palestina Terhadap Konsep Logos Perjanjian Baru. galilee Press, 2018.

Zaluchu, Sonny Eli. "Strategi Penelitian Kualitatif Dan Kuantitatif Di Dalam Penelitian Agama." Evangelikal 4, no. 1 (2020): 28-38. 